\title{
Wazwan the Kashmiri Cuisine - A Caloric Bomb
}

\author{
Mushtaq Ahmad, M.D., 'Sakina Akhter, M.Sc., ${ }^{2}$ Shariq R. Masoodi, D.M. ${ }^{2}$ \\ 'Departments of Medicine, ${ }^{2}$ Endocrinology, Sher-i-Kashmir Institute of Medical Sciences, Soura, Srinagar
}

\section{A B S T R A C T}

Wazwan, the Kashmiri cuisine, is a unique component of Kashmiri culture. Comprising of seven to thirty-six dishes of mutton, chicken, fruits and vegetables, it is served to invited persons (guests) on special occasions. Besides being micro-and macro-nutrient rich (especially in proteins), it is also rich in calories. Though cherished by all, it not feasible for patients suffering with obesity, diabetes, chronic liver disease or kidney disease because of its high caloric and protein content. In this article, the high calorie content of Wazwan is discussed. JMS 2012;15(2):174-75

Key words: Adverse effects, cooking, Kashmiri cuisine, Nutrition education, Wazwan

The origin of Kashmiri cuisine dates back to the 15th century invasion of India by the Emperor Timur, who brought skilled persons of various professions including cooks from Samarkand to Kashmir. ${ }^{1}$ These skilled cooks called 'Wazas' in Kashmiri cook mutton in various forms and have classified them according to the shape the mutton is given. The mutton for different dishes are taken from different parts of sheep, goat, etc. Depending upon the nature of the occasion and financial strength of host, seven to thirty dishes prepared from mutton, chicken, cheese, vegetables and fruits are served (Box 1). These dishes are prepared in copper utensils named in Kashmiri 'Degs' or 'Degchas' depending on size of pot. These pots containing the uncooked preparation are put on logs of burning wood for cooking. These are served in large copper plates called 'Tramies' with rice. Four persons take food in each Tramie. The dishes are served in a particular sequence.

Wazwan besides being cherished by all is rich in many microand macro-nutrients, especially proteins and calories. However, because of later, it not feasible for patients with conditions like chronic liver disease, chronic kidney disease, obesity and diabetes mellitus. In this pilot study, we are reporting the calorie content of various dishes served in Wazwan.

\section{Methods}

This study was conducted during autumn season when most

\section{Correspondence:}

Dr. Mushtaq Ahmad

Assistant Professor

Department of Medicine

Sher-i-Kashmir Institute of Medical Sciences, Soura, Srinagar

E-mail:drmushtaq_01@yahoo.co.in

\begin{tabular}{|lll|}
\hline Box & 1. Dishes served in Wazwan & \\
\hline Item & & Serving ${ }^{*}$ per Tramie \\
\hline 1. & Meethi & 1 serving at 4 places \\
2. & Chicken (Whole) & $1-2$ No. \\
3. & Kabab & $2-4$ No. \\
4. & Tabakmaaz & $2-4$ No. \\
5. & Dani & 1 No. \\
6. & Rista & 4 No. \\
7. & Roganjosh & 4 pieces \\
8. & Tamater Paneer & 1 large piece \\
9. & Aab-Ghosh & 1 large piece \\
10. & Spinach & 1 serving \\
11. & Marchawangan Korma & $4-6$ pieces \\
12. & Goshtaba: & 1 No. \\
13. & Fruit \& vegetable dishes & Variable* \\
\hline * depends upon the nature of occasion and financial strength of the host \\
\hline
\end{tabular}

of marriages in Kashmir take place and Wazwan dishes are prepared in great quantities. One such event was chosen randomly after taking consent from the host and the Vasta Waza (head chef). The waza was asked to keep a record of every ingredient used and the number of servings prepared. Caloric content was estimated by making a list of ingredients and the quantity used in each dish. The calculation of caloric content of various dishes was done using reference values of nutritive value of Indian foods, provided by The National Institute of Nutrition (NIN) Hyderabad. ${ }^{2}$ Because the amount of meat in a Tramie served for four persons varies greatly (usually from $3 \mathrm{~kg}$ to $5 \mathrm{~kg}$ ), the above exercise was repeated three times and average values were calculated. 


\section{Results}

The following 11 Wazwan dishes were studied (in the order in which they are served during the Wazwan feast):

Meethi: Made up of intestine, omentum of sheep.

Chicken: Whole 1-2 chicken depending upon the nature of occasion and financial strength of the host.

Kabab: Two to four kababs, 20 - $30 \mathrm{cms}$ long are placed on the plate. These kababs are made up of fleshy meat which is minced on stony surfaces with a tukni (a wooden instrument). Eggs are added along with various spices while mincing. Then the finely minced meat is wrapped around iron rod for cooking.

Tabakmaaz: Made up of rib cage of sheep, cooked in ghee and served as drypieces.

Dani: Asingle piece of meat on a cortical bone.

Rista: 4 pieces of minced meat of spherical shape.

Roganjosh: 4 pieces of meat.

Tamatar Paneer: Large pieces of cheeze, fried then cooked in spicy tomatogravy.

Aab gosh: 1 piece of sacral area of vertebral column prepared in milk.

Marchawangan korma: Pieces of meat prepared in chilly soup.

Goshtaba: 500 - 750 gms mutton ball made of feshy meat which is minced on stony surfaces with a tukni (a wooden instrument), prepared in spheres then cooked in curd.

The caloric content of dishes served in Wazwan varied from $709 \pm 60$ Calories in 'Dani' to $3597 \pm 1348$ Calories in 'Rista' with an average content of $18484 \pm 3409$ Calories per tramie (Table 1 ). In addition to these mostly mutton preparations, $1-2 \mathrm{Kg}$ of rice are consumed in each Tramie with an average caloric content of $3450 \pm 2050$. This would amount to $21933 \pm 5458$ Calories per Tramie. Presuming that one Tramie will serve four persons, the total calories consumed on an average by each person would be 5483 .

TABLE 1. Calorie content of the Wazwan served dishes

\begin{tabular}{llcc} 
S.No. Name of the Wazwan dish & $\begin{array}{c}\text { Average calorie content } \\
\text { per tramie }\end{array}$ & $\begin{array}{c}\text { Calorie served } \\
\text { per person }\end{array}$ \\
1. & Meethi & $1356 \pm 144$ & 339 \\
2. Chicken & $3597 \pm 1348^{*}$ & 899 \\
3. & Kabab & $2960 \pm 260$ & 740 \\
4. & Tabakmaaz & $1470 \pm 220$ & 367 \\
5. & Dani & $709 \pm 60$ & 177 \\
6. & Rista & $1814 \pm 206$ & 454 \\
7. & Roganjosh & $1322 \pm 102$ & 331 \\
8. & Tamatar Paneer & $1475 \pm 285$ & 369 \\
9. & Aab Ghosh & $934 \pm 244$ & 234 \\
10. Marchawangan Korma & $1059 \pm 255$ & 265 \\
11. Goshtaba & $1787 \pm 287$ & 447 \\
\hline & Total & $18484 \pm 3409$ & 4621 \\
\hline
\end{tabular}

*includes calories from the ghee (clarified butter) used to fry the chicken.

\section{Discussion}

This study shows that an average Wazwan contains some twentythousand plus calories in each Tramie; dishing up some 5483 calories to the invited person. Knowing the amount of fat used in these dishes (in addition to large amounts of mutton), it is not surprising to see that most dishes served in Wazwan have high caloric content. The biggest surprise of the study is large number of calories seen in chicken dishes. This is in contrast to the popular belief that chicken is better than mutton dishes in terms of caloric and fat content. However, when one realizes that waza chicken is fried in ghee and $1-2 \mathrm{Kg}$ of chicken are served in each Tramie, this high caloric content provided by chicken dishes becomes understandable. Ideally, we should have estimated the whole micro- and macro-nutrient content, especially the protein content of Wazwan but that was beyond the scope of this study.

The Wazwan is Kashmir's most formal meal served to a guest; a ritual serving of all the food there is in the house. The ultimate formal banquet in Kashmir is the grand Wazwan which is served during important events like the feast served to bridegroom and his relatives by the bride's relatives at the time of marriage. As many as 36 courses may be served, of which 15-30 preparations are of meat (invariably mutton). Many days of planning go into the making and serving of a Wazwan which is cooked overnight by the Vasta Waza (master chef) and his retinue of wazas. Guests are seated in groups of four and share the meal out of a large metal plate called the Tramie. Normally restricted to occasions of celebration at homes, the Wazwan experience includes table settings for groups of four on the floor where choice dish after dish is served, each aromatic with herbs and the fresh produce of the region. This taste of hospitality must in turn be fully appreciated by the guest, for the wazwan is not a simple meal but a ceremony.

Our study was conducted in the context of managing obesity and diabetes in Kashmir (now very common here) ${ }^{3,4}$ though Wazwan is also not feasible in conditions like chronic liver disease or chronic kidney disease. ${ }^{5}$ One can argue that since this cuisine is used occasionally, hence it cannot be matter of concern in management of such noncommunicable diseases. But knowing that ready-made Wazwan is now available on a fly, it is not uncommon to see Kashmiris taking Wazwan every now and then. Keeping the quantum of calories in view, Wazwan is likely to interfere in the management of glycaemic control of diabetes and weight management of obesity. But this should not make the reader loose site of many advantages that Wazwan can offer. This highly cherished cuisine, being rich in protein, calories, iron and vitamin B12 can be very useful for growing children, pregnant women and lactating mothers, apart from its potential benefit in catabolic states like cancer or burns. To our knowledge, this is the first paper, which is considering Wazwan in this point of view. A search on PubMed using keyword 'Wazwan' in the title did not reveal any paper containing that name. Therefore, there is a need of doing a detailed study on micro- and macronutrient value of Wazwan and doing research for finding out ways to make Wazwan healthier, without compromising on its taste that Kashmiris cherish so much.

In conclusion, our study reveals that Wazwan is a calorie- and fatdense food; on an average, a person consumes about 5483 kilocalories on one occasion. One way to reduce the high caloric of this cuisine, without comprising on its essence, is to reduce the amount served per person like decreasing the portion size.

\section{References}

1. http://en.wikipedia.org/wiki/Kashmiri cuisine

2. Nutritive value of Indian Foods, NIN-ICMR, Hyderabad 500007 India (47-58).

3. Masoodi SR, Wani AA, Wani AI, Bashir MI, Laway BA, Zargar AH Prevalence of overweight and obesity in young adults aged 20-40 years in North India (Kashmir Valley). Diabetes Res Clin Pract 2010;87:e4-6.

4. Zargar AH, Wani AA, Laway BA, Masoodi SR, Wani AI, Bashir MI, Dar FA. Prevalence of diabetes mellitus and other abnormalities of glucose tolerance in young adults aged $20-40$ years in North India (Kashmir Valley). Postgrad Med J2009;85(1003):227-32.

5. National Kidney Foundation: Kidney disease outcomes quality initiative clinical practice guidelines for nutrition in chronic renal failure. 2000;35:1. 